\title{
A Hybrid Landslide Susceptibility Model Obtained from Different Models (Raster or Vector, Expert or Semi-Expert) with the Correct Parameter
}

Mehmet Emin Cihangir ( $\nabla$ m.e.cihangir@gmail.com )

Kahramanmaras Sutcu Imam University Faculty of Science and Letters: Kahramanmaras Sutcu Imam Universitesi Fen Edebiyat Fakultesi https://orcid.org/0000-0001-8881-5308

\section{Research Article}

Keywords: Landslide, Hybrid Model, Raster and Vector-based model, Parameter Selecting

Posted Date: September 7th, 2021

DOl: https://doi.org/10.21203/rs.3.rs-732633/v1

License: (c) (i) This work is licensed under a Creative Commons Attribution 4.0 International License.

Read Full License 


\title{
A hybrid landslide susceptibility model obtained from different models (raster or vector, expert or semi- expert) with the correct parameter
}

\author{
Mehmet Emin CİHANGİR \\ Kahramanmaras Sutcu Imam University, Science and Letter Faculty, Geography Department \\ m.e.cihangir@gmail.com \\ ORCID : https://orcid.org/0000-0001-8881-5308
}

\section{Abstract}

This study aims to determine how to choose the correct parameter for a specific study area in landslide susceptibility and how it gives results in vector or raster-based models. In the literature, factor parameters of landslide preparing and triggering conditions are used deliberately or randomly in raster or vector-based models. In this study, the landslide inventory was analyzed together with geological, topographic-morphological, environmental, and triggering parameters, and the parameters specific to the study area and its scale were decided. In order to obtain high efficiency from the models, the parameter data were taken from the landslide depletion zone. Raster-based models and vector-based models were created according to qualitative and quantitative approaches. Model outputs resulted in close Roc Curve results ranging from 0.79 to 0.92 . The study area was divided into slope units and then the model output data were transferred to these units. In order to make the result easier to use, the units obtained according to the result of each model were combined, thus a single map output was obtained from 5 different raster and vector-based models. Overall, this study presents 1) the importance of the use of landslide inventory and how to use the inventory. 2) Parameters should be selected according to field analysis and field-scale rather than randomly. 3) By combining raster and vector-based on landslide susceptibility studies, make it easier to use as a base map in hazard and risk studies with a single output.

Keywords: Landslide, Hybrid Model, Raster and Vector-based model, Parameter Selecting

\section{Introduction}

Landslide susceptibility studies are the basis for understanding the locality, magnitude, and impact of future landslides for landslide risk and hazard studies. The more accurate the landslide susceptibility map is, the more accurate the landslide hazard and risk maps are. Thanks to Geographical Information Systems, Remote Sensing, and other products related to Computer Technologies, landslide susceptibility approaches have diversified and evolved from the first examples (Brabb and Pampeyan 1972; Carrara 1977) to the present day. Some of those; probability approach based on landslide inventory (Chau et al. 2004; Guzzetti et al. 2005), heuristic approach (direct geomorphological mapping or indirect) (Ayenew and Barbieri 2005; Gorum et al. 2008; Gökceoglu and Aksoy 1996; Pachauri et al. 1998; Pachauri and Pant 1992; Ruff and Czurda 2008; Wachal and Hudak 2000), statistical approach (bivariate or multivariate) (Atkinson and Massari 1998; Carrara et al. 1991; Dai and Lee 2002; Guzzetti et al. 1999; Lee et al. 2004; Lee and Min 2001; Malamud et al. 2004; Nandi and Shakoor 2010; 
Santacana et al. 2003), deterministic approach (Cotecchia et al. 2009; Gökceoglu and Aksoy 1996; Westen and Terlien 1996), In addition to these, in recent years, there are also studies in which these analyzes are carried out with artificial intelligence methods knowledge-based (Chen et al. 2017; Ercanoglu and Gokceoglu 2002; Juang et al. 1992; Kanungo et al. 2006; Phong et al. 2019; Yesilnacar and Topal 2005). Landslide susceptibility studies from the past to the present, while overlay analysis was generally used in susceptibility studies between 19901993 years, In the following years 1993-2005, the use of binary or multivariate statistical approaches was high. In 2005-2008, both multiple and bivariate statistical approaches were used at the same time, besides, Analytic Hierarchy Process (AHP) and Artificial Neural Networks (ANN) models were also used. In 2008-2010, various models were used by comparing ANN, AHP, binary and multivariate statistics, artificial intelligence, and machine learning with each other. After 2011, modifications were made to existing models, and comparisons were made (Cihangir 2018).

When the studies were examined by topic, 2499 direct landslide susceptibility and indirect landslide susceptibility that 1832 landslide hazard and 972 landslide risk studies were conducted. Until today, there were changed in the number and type of factors used in the creation of landslide susceptibility, hazard, and risk maps (Cihangir 2018).

In these studies, geological (lithology, structural lineaments, relationship between structural geological elements and slope, groundwater, sediment thickness, discontinuity density, weathering degree, soil structure, layer position, surface material), topographically-morphological (slope, drainage network and density, relief, surface process, altitude, main or detailed geomorphological unit, slope curvature, aspect, slope length, stream erosive power index, topographic permeability index, topographic wetness index, topographic roughness ratio), environmental (landuse, vegetation, road density) and trigger (climatic, seismic, human) were used. Among these are the most used lithology from the geology group, slope from topographic factors group, landuse from environmental conditions, and climatic data "especially precipitation" from triggering factors (Fig. 4).

Our thoughts, Expert opinion, or statistical methods are used in weighting the factors chosen in both raster and vector-based studies. The expert must have experience of knowledge and geomorphological perspective that the ability to relate cause and effect from. The opinion of the expert who does not have these features may cause the model to be based on an incorrect basis. On the other hand, although some factors seem statistically related to landslides, they may not contribute to the landslide. Another situation is the close similarity between the parameters used. Simultaneous use of a factor or many other similar factors derived from it does not provide statistical benefit (Cihangir et al. 2018; Costanzo et al. 2012; Kavzoglu et al. 2015). Scale preference is also important in explaining the factors affecting the landslide or putting these parameters in a process. The factors decrease or increase depending on the scale of the study. Using too many factor parameters can reduce the accuracy of the results in a model. Because They can reduce the weight of the main factors causing the landslide in the model. Therefore, the landslide type in the model should be uniform and the study area should be a reasonable field of physical morphology such as a medium scale geomorphological basin.

Dividing the study area into physical units can reduce some of the problems. For instance, when using only raster or vector-based on susceptibility maps may cause problems for risk maps. A building raster cell can remain between the high data value and low data value. Or, two vector polygons that have different values can cut 
a building. Therefore, it is more appropriate to take slopes as physical units in raster or vector studies. Also, if there is activity at any point of a slope, it affects the whole slope. Since the whole slope is affected by the first movement, it makes more sense to give the results as a divided slope unit (Carrara et al. 1991).

The use of the landslide inventory is very important as it provides information about the distribution pattern of the existing landslide and the determination of the factors that control the formation of the landslide (Casagli et al. 2004; Cihangir and Gorum 2016; Du et al. 2020; Eeckhaut et al. 2009). Considering the past is the key to the present principle, a current landslide inventory makes landslide susceptibility maps more reliable.

In a classical landslide system, the slope, relief, and altitude values are the lowest in the accumulation zone and depletion zone (Gorum et al. 2008). Even in very large landslides, the lithology and groundwater level of this zone change (Cihangir et al. 2018). Many researchers have applied different methods in the sample data (Clerici et al. 2006; Gorum et al. 2008; Nefeslioglu et al. 2008; Tribe 1991; Yilmaz 2010). When using landslide inventories, it makes more sense to take topographic and geological average data of the depletion zone where the first movement occurred, rather than all parts of the landslide (Cihangir and Gorum 2016). Our opinion is that the selected average value and above model also creates fewer problems as it affects the regions where landslide susceptibility is high.

All this information in accordance with 1) Firstly, this study aims to choose the correct parameter. 2) Secondly, by revising the landslide inventory, the data obtained from the depletion zone are associated with the appropriate parameters. 3) Finally, it is to provide both vector and raster-based models with quantitative, semi-quantitative, and qualitative approaches. Also, it is to provide ease of use in danger and risk steps by combining the model outputs on a single map. All these are created for slide-type landslides according to the (Cruden 1993) classification.

\section{Study Area}

The current study area, Sakarya Basin, covers an area of $\sim 670 \mathrm{~km}^{2}$ between Marmara and the Blacksea Region. It is located at the northwestern portion of Turkey between $40^{\circ} 16^{\prime} 20^{\prime \prime} \mathrm{N}$ to $40^{\circ} 08^{\prime} 54^{\prime \prime} \mathrm{N}$, and $30^{\circ} 23^{\prime} 26^{\prime \prime} \mathrm{E}$ to $30^{\circ} 51^{\prime} 14^{\prime \prime} \mathrm{E}$ (Fig. 1). The study area has steep topographic relief and its elevation ranges from $857.5 \mathrm{~m}$ to 1486 $\mathrm{m}$ above the mean sea level (Fig. 3A and C). The slope of the area varies between $13^{\circ}$ and $68^{\circ}$ (Fig. 3B). According to the gauges of the Yenipazar meteorology station, the annual average precipitation is $38 \mathrm{~mm}$. The highest rainfall occurs in December and January, and the least rainfall occurs in July-August. Geologically, During the Mesozoic period, the Tethys ocean was separating the Sakarya continent in the north and the Anatolide-Tauride block in the south. Later, the Tethyan ocean narrowed by subduction to the north in the Late Cretaceous. At the beginning of the Tertiary, the Sakarya continent in the north and the Anatolide-Tauride block in the south collided. This continent-continent collision caused deformation and Alpine orogeny in the region (Okay 2011; Yilmaz and Oezel 2008). Various rock types varying from the Paleozoic to the present are exposed in the study area, which is located in the Sakarya Zone and the Tauride-Anatolide tectonic union. Oldest to youngest; Paleozoic MagmaticAmphibolite-Gneiss-Schist (Pzs) and Granite (Csg), Jurrasic Cherty limestone (JKs), Cretaceous aged Rhyolite (Rhyolite), Clayey limestone (Kyed) and Sandstone-Mudstone-Limestone (Kyet), Paleogene aged Limestone 
(Tks), Sandstone-shale-limestone-tuff (Kye) and Conglomerate-sandstone-mudstone (Tk), Quaternary aged Alluvium (Qa) and Travertine (Qt) are available. Among these rocks, there are 39\% Sandstone-MudstoneLimestone (Kyet) and 29.9\% Conglomerate-sandstone-mudstone (Tk) in the study area (Fig. 3D) (MTA 2002).

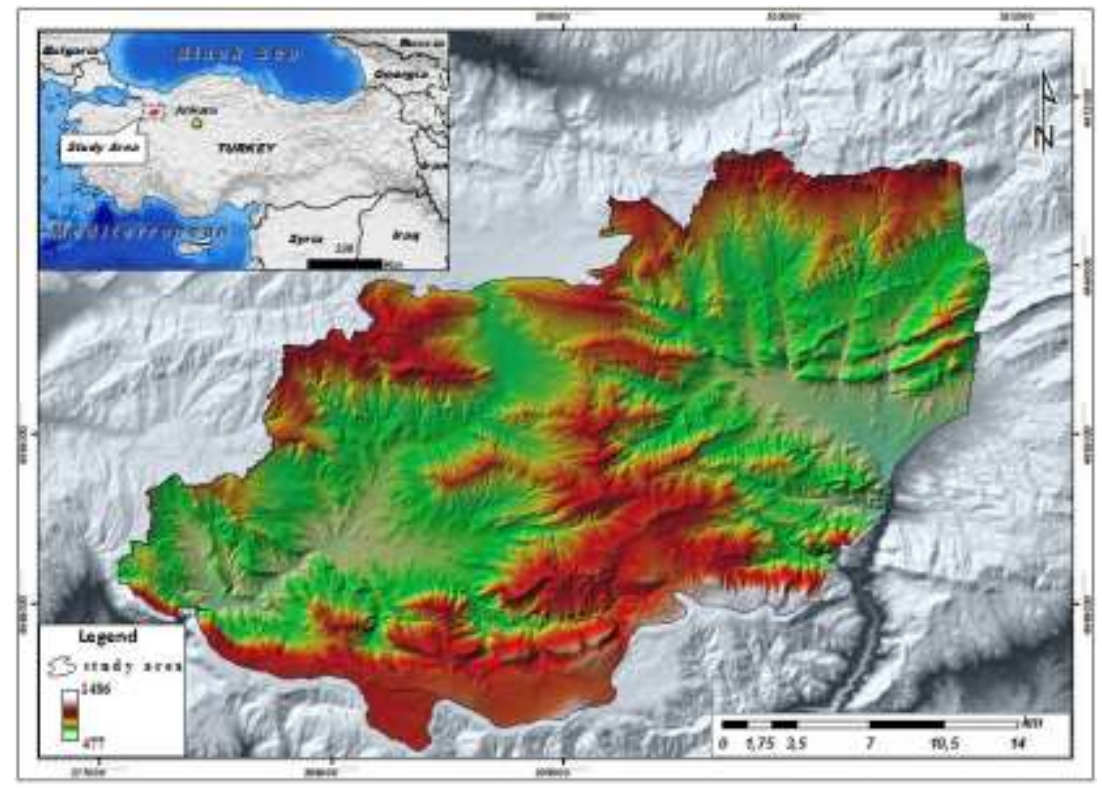

Fig. 1: Location of the study area. 

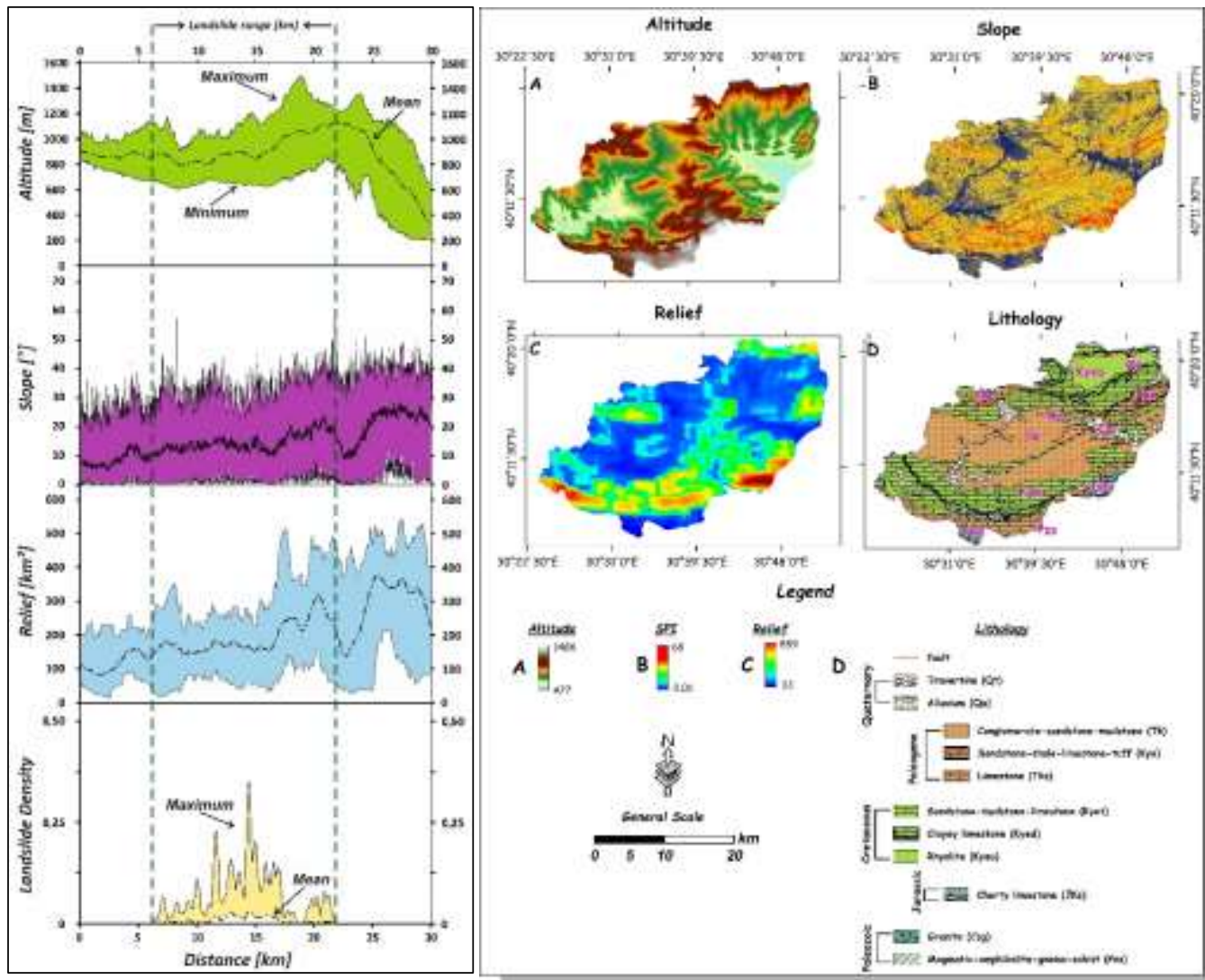

Fig. 2: Altitude, slope, relief, and landslide distribution N-S direction swath profiles of the study area.

Fig. 3: Illustration relief, elevation, lithology, and slope map of the study area

\section{Factor parameter selection}

Selecting the right parameter in a susceptibility model means setting up a good base. The first rule of choosing the right parameter is to question which parameters are most used in terms of landslide control and what is their importance in regional landslide studies in the literature. Accordingly, 200 studies selected among international publications that received at least 20 citations in the Web of Science between 1990-2020 were researched (Fig. 4). The use of conditions and triggering parameters that control the distribution conditions of landslides were examined in terms of the literature in these studies. Geological (lithology and structural lineaments), topographic-morphological (slope, altitude, and aspect), environmental (landuse, vegetation, road density), and triggering (climate) factors were used in most studies (Fig. 4). Topographic-morphology data, also known as landslide preparing conditions, were observed in almost all studies. However, according to the studies, it was seen that factors that were not effective in the study area were used randomly in most of these studies. 


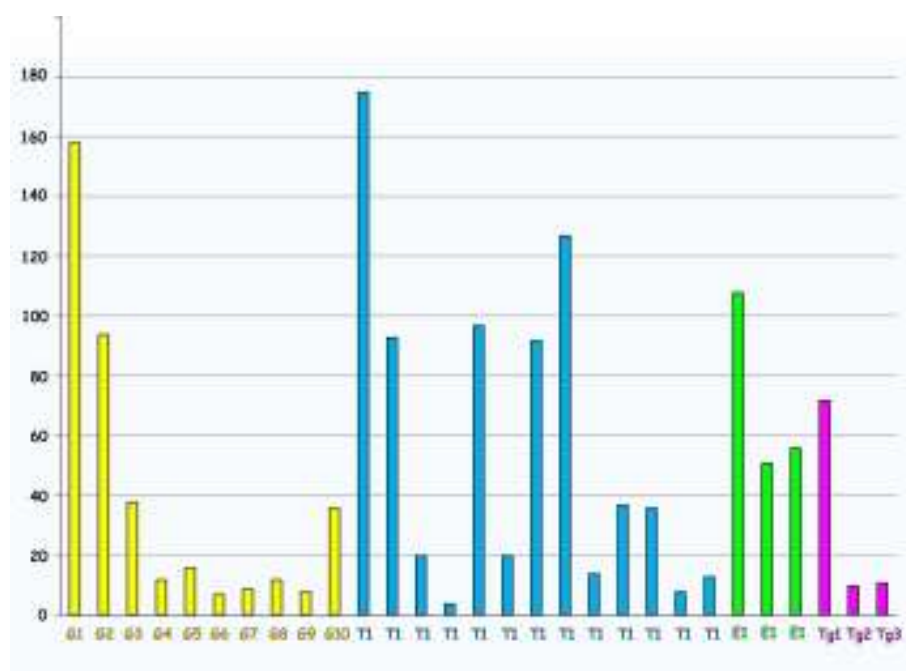

Fig. 4: Parameters used in landslide susceptibility (200 studies that selected among international publications that received at least 20 citations)

Lithology (J1), Structural Lineations (J2), Relationship between structural geological elements and slope (J3), Groundwater (J4), Sediment thickness (J5), Discontinuity density (J6), Weathering degree (J7), Soil structure (J8), Layer positions (J9), Surface material. (J10), Slope (T1), Drainage network and density (T2), Relief (T3), Surface process (T4), Elevation (T5), Main or detailed geomorphological unit (T6), Slope curvature (T7), Aspect (T8), Slope length (T9), Stream power index (T10), Topographic Wetness Index (T11), Topographic permeability index (T12), Topographic roughness ratio (T13), Landuse (Q1), Vegetation (Q2), Road density (Q3), Climatic (Tg1), Seismic (Tg2), Human (Tg3).

After collecting information about the study area and understanding the processes that control the landslide, it is thought that selecting model parameters will make the results more reliable. At the same time, It creates an idea to know which factors are used in which regions on the landslide by using past studies. In addition, Taken swath profiles from the study area guide the decision-making expert in understanding the factors controlling the landslide (Pérez-Peña et al. 2017). When Swath analysis is evaluated together with the landslide inventory, it reveals the variability of the values of the factors with landslides according to the non-landslide area. In this study, transition to landslide and non-landslide areas mostly were detected in lithology, slope, altitude, and relief parameters via swot analysis (Fig. 2). According to the results of the swath analysis, landslides are more intense between 800-1000 m elevation values. The elevation between these values affects the temperature and humidity conditions and accordingly the weathering processes. Areas higher than $1000 \mathrm{~m}$ areas cover structural flatnesses at some places. Landslides have occurred intensively between 200-450 relief values. Hillslopes that have high relief values provide the necessary profile conditions for the process-form system. At the same time, these conditions affect the landslide velocity. Landslides are common between 7-30 slope values. These slope values that affect the shear stress of the materials on the hillslope are suitable for soil formation at the semi-humid climate regions. Since the study includes slide-type landslides, landslides have rarely occurred at slope values above $45^{\circ}$ where the rock surfaces are formed (Fig. 2). 


\section{A Hybrid Model for Landslide susceptibility}

\section{I.I Material and Methods}

TOPO DEM with $10 \mathrm{~m}$ resolution was used for altitude data. $10 \mathrm{~m}$ resolution slope values were calculated from Topo DEM. In addition, relief values were calculated from the elevation differences in a rectangular area of $2000 \mathrm{~m}^{2}$. Lithology was obtained from 1: 100000 scale General Directorate of Mineral Research and Exploration maps (MTA 2002). The current landslide inventory of the study area was determined from satellite images Landsat. Depletion zones of these landslides were determined by taking profiles from hillslope. In addition to giving an idea about which parameters should be used, Swat profiles contributed to the classification of parameters by detecting the data distribution in the landslide area. Thus, the spatial relationship between the landslide and data that lithological units, relief, elevation, and slope were revealed via Swat profiles analysis. The study area was divided into physical slope units. Five models were run on raster and vector basis. Raster and vector model outputs were transferred to slope units. Finally, five models were combined to create a single model (Fig. 5).

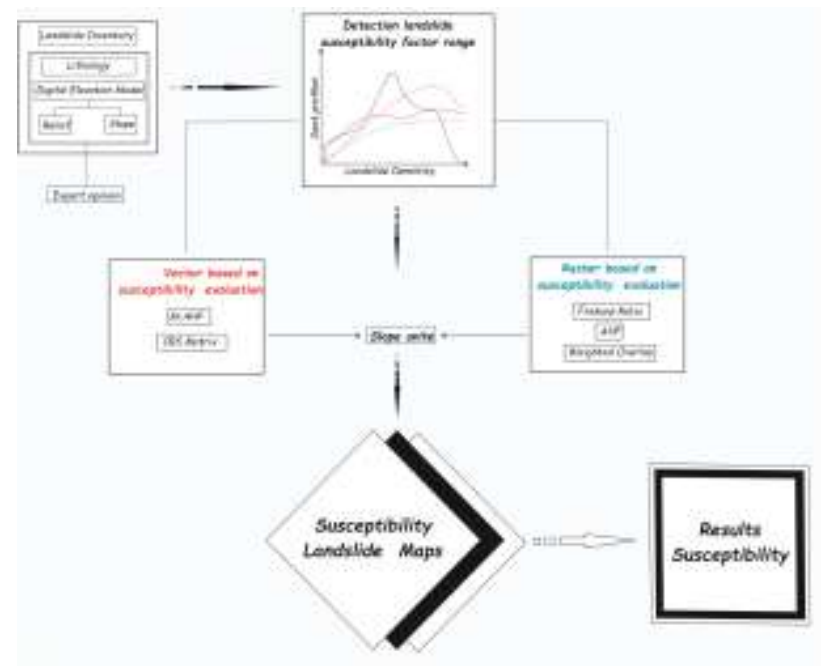

Fig. 5: General methodology flowchart

\subsection{Applying the Model}

In this study, various qualitative, quantitative, and semi-qualitative models were selected to run on raster and vector basis. Frequency Ratio (FR), Analytic Hierarchy Process (AHP), and Weighted Overlay (WOM) models were used as rasters. CBS Matrix Model (CBS MM) and Modified Analytic Hierarchy Process (M-AHP) models were used as vectors. Quantitative (FR and CBS MM), semi-quantitative (AHP and M-AHP), and qualitative (WOV) approaches were evaluated in this study. Thus, the study presents examples according to different approaches. 


\subsubsection{Frequency Ratio Model (FR)}

Frequency Ratio (FR) is a statistical approach based on the probability model whose method is applied to evaluate landslide susceptibility (Lee and Pradhan 2007). Frequency ratio is defined as the ratio of the probability of an event occurring to the probability of not happening (Erener and Düzgün 2010).

$$
F R=\frac{N_{i}^{p} / N}{N_{i}^{l_{p}} / N^{i}}
$$

$$
R F=\frac{F k_{i}^{c l}}{\sum F R} * 100
$$

$$
P R=\frac{R F_{\max }-R F_{\min }}{\Sigma_{\min }^{R F}}
$$

Frequency Ratio; FR Where $N_{i}^{p}$ is the number of pixels in each landslide conditioning factor class, $\mathrm{N}$ is the number of all pixels in total the study area. $N_{i}^{l p}$ is the number of pixels in each landslide conditioning factor class, $N^{l}$ is the number of all pixels in total (Eq. 1). Relative Frequency RF, Where $\sum F R$ is the total value of classes belonging to each factor. $F R_{i}^{c l}$ is the FR value for each class (Eq. 2). Prediction Rate PR, $R F_{\max }$ is the largest value of each factor in the classes. $R F_{\min }$ is the smallest value of each factor in the classes. $\Sigma_{\min }^{R F}$ is the minimum value of all factors in classes (Eq. 3) (Lee and Pradhan 2007; Lee and Talib 2005)

A landslide susceptibility map is produced by multiplying each parameter subgroup with the calculated "RF" value and each factor parameter with "PR". In this study, the frequency ratio was used to create a raster susceptibility map (Fig. 8E).

\subsubsection{Weighted Overlay Model (WOM)}

Weighted Overlay analysis can be interpreted as multi-layer and multi-criteria evaluation. The result layer is obtained by weighing more than one raster layer relative to each other and within themselves and then overlapping them (Basharat et al. 2016; Shit et al. 2016). This layer includes areas that are suitable and not suitable for the criteria determined as a result of its evaluation (Roslee et al. 2017). The analysis combines the following steps: It reclassifies the values in the input raster according to a common evaluation scale or suitability or a similar unifying scale. Each input raster cell values are multiplied by the degree of importance raster. Adds to 
the resulting cell values to generate the output raster. Each layer in a raster are weighted according to their importance or impact percent. The sum of the assigned values must equal 100.

In this study, the selected factors were weighted on a raster basis with expert opinion. The landslide content of the factors was also considered in expert weighting (Table 9). Also, the frequency ratio was used to create a raster susceptibility map in this study (Fig. 8G).

\subsubsection{Analytical Hierarchy Process (AHP)}

Modified Analytical Hierarchy Process (AHP) is an expert opinion-based method that can be monitored and calibrated at every stage of the analysis process (Saaty 1980). When AHP decision hierarchy is defined; It can also be explained as a decision making and estimation method that gives the percentage distributions of decision points according to the factors affecting the decision (Nefeslioglu et al. 2013; Saaty 1980). The first step is to define the problem in which decision points are determined and the factors affecting them are determined (Nefeslioglu et al. 2013; Saaty 1980). The second step is to create comparison matrices between factors (Yaralığlu 2004) (Eq. 4). When using these factors, their importance degree is determined (

) (Saaty 1980). Comparisons are made for all values above the diagonal of 1 in the comparison matrix.

(Eq. 5 is used for the components below the diagonal (Nefeslioglu et al. 2013; Saaty 1980). In the third stage; In order to determine the percentage significance distributions of the factors, column vectors that form the matrix for comparing the weights of the factors in the whole are used. " $n$ " column vectors [B] including " $n$ " cases are calculated (Eq. 6). Eq. 7 uses to calculate the "B" column vectors. The "C" matrix is obtained by combining the B column vectors calculated for the factors in a matrix format. By using the " $\mathrm{C}$ " matrix (Eq. 8), percentage significance distributions ("W" Vector) showing the relative importance values of the factors are obtained (Eq. 9). In the fourth step, the Consistency Ratio (CR) is calculated to measure the consistency in factor comparisons. The calculation of CR is based on comparing the number of factors with a coefficient called the Basic Value $(\lambda)$ (Nefeslioglu et al. 2013; Saaty 1980). In order to calculate the " $\lambda$ ", firstly the matrix multiplication of the "A" comparison matrix and the "W" priority vector is performed. The column vector " $\mathrm{D}$ " is obtained (Eq. 10). By dividing the reciprocal elements of the column vector " $D$ " and column vector "W", the "E" factor for each evaluation factor is obtained. The arithmetic mean of these values gives the Basic Value $(\lambda)$ for the comparison (Eq. 11) By using the " $\lambda$ ”, the Consistency Index (CI) is calculated (Eq. 12). In the evaluation of consistency, the value of CI is divided by a correction value called the Random Index (RI) and the value of CR is calculated (Eq. 
13) (Yaralığlu 2004). A calculated CR value below 0.10 indicates that the comparison matrix provided by the expert is consistent (Nefeslioglu et al. 2013; Saaty 1980). In the fifth step, percentage importance distributions of the factors at the " $\mathrm{m}$ " decision point are found. One-to-one comparisons and matrix operations are repeated for the number of factors (n). At this stage, "G" used in decision points for each factor forms the dimension of the comparison matrix (Nefeslioglu et al. 2013; Saaty 1980). After each comparison process, "S" column vectors showing the percentage distributions of the factor whose dimension is evaluated according to the decision points are obtained (Eq. 14). The sixth stage finds the distribution of results in decision points. This stage consists of " $\mathrm{K}$ " Decision matrice that is formed n number dimensional " $\mathrm{S}$ " column vector and dimensional (Eq. 15). When the resulting decision matrix is multiplied by the column vector " $\mathrm{W}$ ", the "L" column vector with $\mathrm{m}$ elements is obtained (Eq. 16). Finally, "W" vector coefficient value is given to each factor class for AHP. In this study, the AHP was used to create a raster susceptibility map (Fig. 8F). Until this stage, AHP will be the continuation of it M-AHP for vector susceptibility map.

$A=\left[\begin{array}{cccc}a_{11} & a_{12} & \ldots & a_{1 n} \\ a_{21} & a_{22} & \ldots & a_{2 n} \\ \cdot & & & \ddots \\ \vdots & & & \ddots \\ a_{n 1} & a_{\mu 2} & \ldots & a_{n n}\end{array}\right]$

\begin{tabular}{cc}
\hline Intensity of Importance & \multicolumn{1}{c}{ Value explanation } \\
\hline \hline $\mathbf{1}$ & Two elements contri bute equally to the objective \\
\hline 5 & $\begin{array}{l}\text { Experience and judgment slightly favor one element } \\
\text { over another } \\
\text { Experience and judgment strongly favor one } \\
\text { element over another } \\
\text { One element is favored very strongly over another; } \\
\text { its dominance is demonstrated in practice } \\
\text { The evidence favoring one element over another is } \\
\text { of the highest possible order of affirmation } \\
\text { Intermediate values }\end{array}$ \\
\hline 2 &
\end{tabular}

Table 1:The importance of comparison matrices.

$$
a_{j i}=\frac{1}{a_{i j}}
$$

$$
B_{i}=\left[\begin{array}{c}
b_{11} \\
b_{21} \\
\cdot \\
\cdot \\
\cdot \\
b_{n 1}
\end{array}\right]
$$




$$
b_{i j}=\frac{a_{i j}}{\sum_{i=1}^{n} a_{i j}}
$$

$$
C-\left[\begin{array}{cccc}
c_{11} & c_{22} & \ldots & c_{1 n} \\
c_{21} & c_{22} & \ldots & c_{2 n} \\
\cdot & & & \cdot \\
\cdot & & & \ddots \\
\cdot & & & \cdot \\
c_{n 1} & c_{n 3} & \ldots & c_{n n}
\end{array}\right]
$$

$$
w_{i}=\frac{\sum_{j=1}^{n} c_{i j}}{n} \longrightarrow W=\left[\begin{array}{c}
w_{1} \\
w_{2} \\
\cdot \\
\cdot \\
\cdot \\
w_{n}
\end{array}\right]
$$

$$
D=\left[\begin{array}{cccc}
a_{11} & a_{12} & \ldots & a_{1 n} \\
a_{21} & a_{22} & \ldots & a_{2 n} \\
\cdot & & & \cdot \\
\cdot & & & \cdot \\
\cdot & & & \cdot \\
a_{n 1} & a_{n 2} & \ldots & a_{n n}
\end{array}\right] x\left[\begin{array}{c}
w_{1} \\
w_{2} \\
\cdot \\
\cdot \\
\cdot \\
w_{n}
\end{array}\right]
$$

$$
E_{i}=\frac{d_{i}}{w_{i}} \longrightarrow \lambda=\frac{\sum_{i=1}^{n} E_{i}}{n}
$$

$$
\mathrm{CI}=\frac{\lambda-\mathrm{n}}{\mathrm{n}-1}
$$

(Eq. 12) 


$$
\mathrm{CR}=\frac{\mathrm{CI}}{\mathrm{RI}}
$$

$$
S_{i}=\left[\begin{array}{c}
s_{11} \\
s_{21} \\
\cdot \\
\cdot \\
\cdot \\
s_{m 1}
\end{array}\right]
$$

$$
K=\left[\begin{array}{cccc}
s_{11} & s_{12} & \ldots & s_{1 n} \\
s_{21} & s_{22} & \ldots & s_{2 n} \\
\cdot & & & \cdot \\
\cdot & & & \cdot \\
\cdot & & & \cdot \\
s_{m 1} & s_{m 2} & \ldots & s_{m n}
\end{array}\right]
$$

$$
L=\left[\begin{array}{cccc}
s_{11} & s_{12} & \ldots & s_{1 n} \\
s_{21} & s_{22} & \ldots & s_{2 n} \\
\cdot & & & \cdot \\
\cdot & & & \cdot \\
\cdot & & & \cdot \\
s_{m 1} & s_{m 2} & \ldots & s_{m n}
\end{array}\right] x\left[\begin{array}{c}
w_{1} \\
w_{2} \\
\cdot \\
\cdot \\
\cdot \\
w_{n}
\end{array}\right]=\left[\begin{array}{c}
l_{11} \\
l_{21} \\
\cdot \\
\cdot \\
l_{m+1}
\end{array}\right]
$$

\subsubsection{Modified Analytical Hierarchy Process (M-AHP)}

M-AHP (Modified Analytical Hierarchy Process) is the method suggested by Nefeslioğlu et al. (2013) in order to eliminate the uncertainty arising from the subjective evaluation of AHP method. There are two differences between AHP and M-AHP (Nefeslioglu et al. 2013).

The comparison matrix is not prepared by the expert. The expert only gives the maximum scores for each factor in the system. The factor score difference matrix is then prepared. The factor score difference values are normalized depending on the maximum factor score in the system. The dimension of the sampling space in the system is determined according to the maximum factor score given by the expert. The factor comparison matrix is constructed by considering the modified importance value scale (Nefeslioglu et al. 2013).

The second group of differences is related to the evaluation of the importance distributions of the conditioning factors on the decision points. Each factor is normalized depending on its own maximum score in this stage. The linear distances between the normalized factor score and the decision points on a closed interval of 
$[0,1]$ on a numerical axis are measured. The decision point comparison matrix is constructed by considering the modified importance value scale (Nefeslioglu et al. 2008).

Since the landslide occurs along a slope, the model was applied to slope units. Therefore, the study area was divided into 2597 geomorphological slope units. The average value information of the factor parameters that cause landslide susceptibility was transferred to these slope units. These parameters were ranked according to their importance and points were assigned. In the next step, $2597 \mathrm{M}$-AHP analyzes were performed for each model. In each model, the scores of the decision information of each slope unit that is low, medium, and high were entered. The following explanation shows the steps for only one slope unit.

First, the factor score difference matrix and the normalized factor score difference matrix were created for the model (Table 1). In the second stage, the table of significance values (Table 3) and the comparison matrix ("A" matrix) between factors are determined (Table 4). In the third stage, percent significance distributions of factors are determined ("C" matrix and "W" priority vector) (Table 5). In the fourth stage, consistency in factor comparisons is measured. The vector " $\mathrm{D}$ " is the sum of the product of the "W" values of each priority vector of each row of the "A" matrix. "E" is obtained with the ratio of "D" to the priority vector of "W" (Table 6). The $\lambda$ obtained by the mean of the vector "E" is equal to 4. 08. The consistency index (see Eq. 12) is 0.03 . The random index is 1 . The consistency ratio (see Eq. 13) for the comparison matrix and the weight vector [W] was calculated to be 0.03 . According to this value, it can be concluded that the comparison matrix constructed for the relevant slope unit based on the instant factor scores is consistent and rational. The evaluation of the decision points and the resultant distribution constitutes the fifth stage. To evaluate the importance distributions of the conditioning factors on these three decision points (low, moderate, and high) (Fig. 6), the [G] matrices were first constructed, and then the $[\mathrm{S}]$ vectors for each conditioning factor were calculated. When it comes to this stage, each parameter was normalized over its own maximum score. Linear distances of each parameter to decision points were evaluated on a normalized number line in the interval $[0,1]$ (Nefeslioglu et al. 2013).

Sample analysis is shown for 3 Decision Points (DP) regarding the landslide susceptibility parameter (C1; Normalized Parameter Score $=1.000$ ). Also, this analysis should be made for C2, C3 and C4 (Nefeslioglu et al. 2013). DP-1, DP-2 and DP-3 decision points determined for the parameter " $\mathrm{C} 1$ " (Table 7) were also made for "C2" and "C3". The high result value at the decision points constitutes the final result of the slope unit. After determining "C1", "C2", "C2" and "C4" decision points, the result distribution was obtained.

This process was applied one by one in the study area for 2597 slope units. The low, medium and high decision of each model was transferred to the slope unit. Finally, these results were normalized (Fig. $9 \mathrm{H}$ ).

Table 2: The factor score difference matrix " $\mathrm{A}$ " The normalised factor score difference matrix " $\mathrm{B}$ ". 


\begin{tabular}{c|cccc} 
A & C1 & C2 & C3 & C4 \\
\hline C1 & 0.00 & 2.00 & 3.00 & 7.00 \\
C2 & 0.00 & 1.00 & 5.00 & \\
C3 & 0.00 & 4.00 & & \\
C4 & 0.00 & & &
\end{tabular}

\begin{tabular}{c|cccc} 
B & C1 & C2 & C3 & C4 \\
\hline C1 & 0.00 & 0.22 & 0.33 & 0.78 \\
C2 & 0.00 & 0.11 & 0.56 & \\
C3 & 0.00 & 0.44 & & \\
C4 & 0.00 & & &
\end{tabular}

Table 3: The modified importance value scale (modified by Nefeslioglu et al. (2013) after Saaty,1980).

\begin{tabular}{|c|c|c|c|c|c|c|c|c|c|c|}
\hline \multicolumn{11}{|c|}{ Normalized factor score difference } \\
\hline & & 0 & $\begin{array}{c}0.000- \\
0.125\end{array}$ & $\begin{array}{c}0.125- \\
0.250\end{array}$ & $\begin{array}{l}0.250- \\
0.375\end{array}$ & $\begin{array}{c}0.375- \\
0.500\end{array}$ & $\begin{array}{l}0.500- \\
0.625\end{array}$ & $\begin{array}{c}0.625- \\
0.750 \\
\end{array}$ & $\begin{array}{c}0.750- \\
0.875 \\
\end{array}$ & $\begin{array}{l}0.875 \\
1.000\end{array}$ \\
\hline \multirow{2}{*}{$\begin{array}{c}\text { Importance } \\
\text { value }\end{array}$} & $>0$ & 1 & 2 & 3 & 4 & 5 & 6 & 7 & 8 & 9 \\
\hline & $<0$ & 1 & 0,5 & 0,333 & 0,25 & 0,2 & 0,167 & 0,143 & 0,125 & 0,111 \\
\hline
\end{tabular}

Table 4: The factor comparison matrix; the matrix (A).

\begin{tabular}{|ccccc|}
\hline \multicolumn{5}{c|}{ "A" Matrix } \\
\hline \hline C1 & 1.00 & 3.00 & 4.00 & 6.00 \\
C2 & 0.33 & 1.00 & 2.00 & 4.00 \\
C3 & 0.23 & 0.50 & 1.00 & 3.00 \\
C4 & 0.17 & 0.25 & 0.33 & 1.00 \\
\hline
\end{tabular}

Table 5: Percent distribution of importance.

\begin{tabular}{c|c|c|c|c}
\hline \multicolumn{5}{c}{ C Matrix } \\
\hline \hline C1 & 0.57 & 0.63 & 0.55 & 0.43 \\
\hline C2 & 0.19 & 0.21 & 0.27 & 0.29 \\
\hline C3 & 0.14 & 0.11 & 0.14 & 0.21 \\
\hline C4 & 0.10 & 0.05 & 0.05 & 0.07 \\
\hline
\end{tabular}

\begin{tabular}{|c|}
\hline W vector \\
\hline 0.54 \\
0.24 \\
0.15 \\
0.07 \\
\hline
\end{tabular}

Table 6: Vector D and E

\begin{tabular}{|c|c|c|c|c|c|c|c|}
\hline \multicolumn{5}{|c|}{ "A" Matrix } & \multirow[t]{2}{*}{$\mathbf{W}$} & \multirow[t]{2}{*}{ "D" Vector } & \multirow[t]{2}{*}{ "E" Vector } \\
\hline & C1 & C2 & C3 & C3 & & & \\
\hline C1 & 1.00 & 3.00 & 4.00 & 6.00 & 0.54 & 2.26 & 4.15 \\
\hline C2 & 0.33 & 1.00 & 2.00 & 4.00 & 0.24 & 0.99 & 4.11 \\
\hline C3 & 0.23 & 0.50 & 1.00 & 3.00 & 0.15 & 0.60 & 4.04 \\
\hline C4 & 0.17 & 0.25 & 0.33 & 1.00 & 0.07 & 0.27 & 4.03 \\
\hline
\end{tabular}




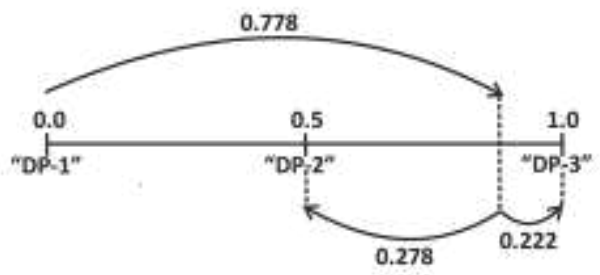

Fig. 6: Determination of Decision Point (DS).

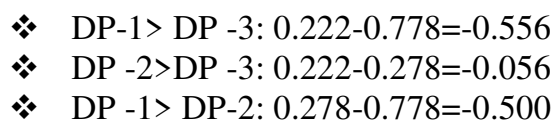

Table 7: Determination of "C1" parameter decision points and distribution of results.

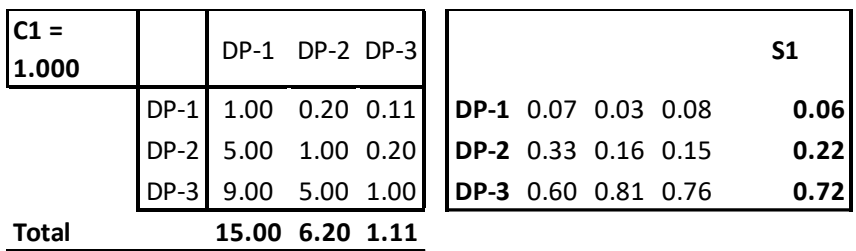

Table 8: Result distribution at decision points (Red is the final result).

\begin{tabular}{|ccccc|c|c||c|}
\hline \multicolumn{5}{|c|}{ The decision matrix (K Matrix) } & "L" Vector & $\begin{array}{c}\text { Landslide } \\
\text { Susceptibility }\end{array}$ \\
\hline \hline & C1 & C2 & C3 & C4 & & \\
DP-1 & 0.06 & 0.08 & 0.10 & 0.57 & DP-1 & 0.10 & LOW \\
DP-2 & 0.22 & 0.34 & 0.62 & 0.34 & DP-2 & 0.32 & MEDiUM \\
DP-3 & 0.72 & 0.57 & 0.28 & 0.08 & DP-3 & 0.59 & HiGH \\
\hline
\end{tabular}

\subsubsection{CBS Matrix Model (CBS MM)}

This model, which is a quantitative approach, is carried out using a matrix in a GIS environment, depending on all possible combinations among the landslide-causing factor types and their correlation with the landslide inventory (DeGraff and Romesburg 2020; Fernández et al. 1999; Irigaray et al. 2007).

The "Landslide Matrix" (Fig. 7a) was created by calculating the surface area affected by the landslide in each factor combination depending on the landslide inventory (depletion zone of landslide) (Fernández et al. 1999; Irigaray et al. 2007). The "Management Unit Matrix" (Fig. 7b) was created by calculating the total surface area occupied by each factor combination (Fernández et al. 1999; Irigaray et al. 2007). "Landslide Susceptibility Matrix" (Fig. 7c; Fig. 8I) was obtained by dividing the values corresponding to the "Landslide Matrix" by the values of the "Management Unit Matrix" (Fernández et al. 1999; Irigaray et al. 2007). The values in the landslide 
susceptibility matrix represent the ratio of the study area to the total landslide and the relative susceptibility of each combination of factors at each point (Fernández et al. 1999; Irigaray et al. 2007).

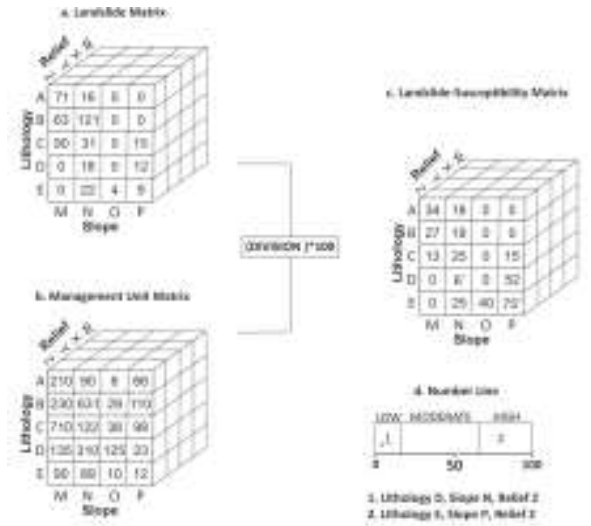

Fig. 7: Illustration of the determination of landslide susceptibility by the GIS matrix method

(changed from (Fernández et al. 1999; Irigaray et al. 2007).

Table 9: Coefficient of all parameter classes for Frequency Ratio, Analytical Hierarchy Process,

Weighted Overlay, and Modified Analytical Hierarchy Process.

\begin{tabular}{|c|c|c|c|c|c|c|c|c|c|}
\hline \multirow[b]{2}{*}{ Dablivers } & \multirow[b]{2}{*}{ dins } & \multirow[b]{2}{*}{$\mathrm{kClas}$} & \multirow{2}{*}{$\begin{array}{c}\text { Standilde } \\
\text { eantent af the } \\
\text { class }\end{array}$} & \multicolumn{2}{|r|}{ m } & \multirow{2}{*}{$\begin{array}{l}\text { M.AHar } \\
\text { Scair } \\
\text { Value }\end{array}$} & $A \leftrightarrow$ ? & \multicolumn{2}{|r|}{ WoN } \\
\hline & & & & $\begin{array}{l}\text { Salie } \\
\text { Vsive }\end{array}$ & $\begin{array}{c}\text { Ph IS } \\
\text { influence) }\end{array}$ & & $\begin{array}{c}\$ \\
\text { infueser }\end{array}$ & $\begin{array}{l}\text { Sear } \\
\text { Value }\end{array}$ & intorenas \\
\hline \multirow{4}{*}{ Sobe } & Q.? & $\begin{array}{l}22 \pi \\
259\end{array}$ & $\sum_{362}^{2}$ & $\begin{array}{l}\text { MII } \\
\text { Iff }\end{array}$ & \multirow{4}{*}{ tan } & $\frac{i}{a}$ & & $\frac{1}{4}$ & \multirow{4}{*}{27} \\
\hline & $54 \pi$ & $22=$ & nez & is: & & 3 & ust & $=$ & \\
\hline & $m x$ & 20 & It: & ta & & 6 & & 5 & \\
\hline & ise & tse & 0 & 230 & & 3 & & 1 & \\
\hline \multirow{6}{*}{ Amas: } & 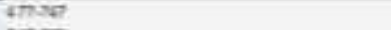 & the & 16 & a05 & \multirow{6}{*}{$2 \mathrm{at}$} & 2 & \multirow{6}{*}{ ast } & I & \multirow{6}{*}{ II } \\
\hline & रक्ष & zaw & is & es: & & 3 & & $=$ & \\
\hline & amses & ant & Int & Qnz & & 2 & & 4 & \\
\hline & vatsen & $x e=$ & 281 & 6) & & a & & $a$ & \\
\hline & 2207205 & $x \in$ & the & 27 & & I & & s & \\
\hline & inguge & $13 \pm$ & 90 & 000 & & 1 & & 1 & \\
\hline \multirow{13}{*}{ amets } & Danswioverice & 20 & ab & 800 & \multirow{13}{*}{$2 \pi$} & I & & $\mathrm{I}$ & \multirow{13}{*}{$2 x$} \\
\hline & eansoration & $a=$ & as & eas & & 2 & & $\mathrm{z}$ & \\
\hline & 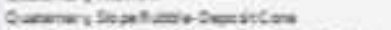 & $2 a$ & at. & ate & & $i$ & & $z$ & \\
\hline & 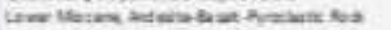 & in al & is & 221 & & 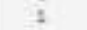 & & 2 & \\
\hline & 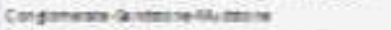 & xing & mo & 33 & & \# & & 1 & \\
\hline & 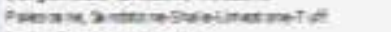 & 2020 & me & wa & & 3 & & 1. & \\
\hline & 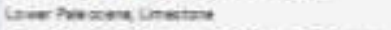 & an & es & eses & & $=$ & ast & 2 & \\
\hline & 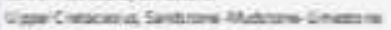 & $\mathrm{a} \equiv$ & 23 & sae & & 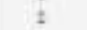 & & , & \\
\hline & 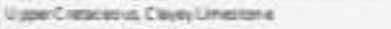 & eas & 22 & 354. & & 2 & & 2 & \\
\hline & Uecongansin & Ints & 12 & 43 & & 1 & & 1. & \\
\hline & 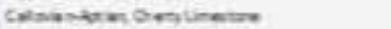 & $\cos$ & is & as & & a & & 1 & \\
\hline & 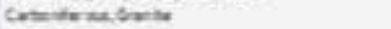 & ase & es & ese & & i & & 1 & \\
\hline & 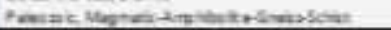 & iat & as & 600 & & 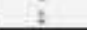 & & $=$ & \\
\hline \multirow{5}{*}{ exe } & $33 \cdot 159$ & & 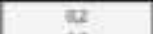 & Q803 & \multirow{5}{*}{ 뇨 } & 1 & \multirow{5}{*}{$a=$} & 1 & \multirow{5}{*}{ at } \\
\hline & 130:an & $x=$ & 15 & 60 & & 3 & & 1 & \\
\hline & $200-3$ & $A=$ & 6es & 156 & & " & & 3 & \\
\hline & 3969 & 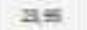 & Ine & Uit & & 7 & & $\pi$ & \\
\hline & $4508 n$ & SAI & 12 & 224 & & 1 & & 1 & \\
\hline
\end{tabular}




\section{Discussion and conclusions}

There may be sharp transitions between neighboring raster cells in raster-based model studies. The neighboring pixel of a pixel with very high susceptibility may have very low landslide susceptibility. Also, some cells do not show the morphological continuity that defines a landslide. Assuming that the pixel with a high value does not affect the neighboring pixel and this change depending on the resolution detail reduces the reliability of the results. The reliability of the results of the hazard and risk studies built on these landslide susceptibility maps will also be affected by that, or the decisions of the management mechanisms that make decisions based on them. Do natural events such as landslides have such sharp geometric boundaries? Especially when there are landslides with different morphological structures. Another situation is observed in vector-based results. they can produce landslide susceptibility that has many fragments and sharp forms on a slope.

Slope units were preferred to avoid raster and vector morphological shapes that do not describe all this landslide, and because instability on a slope affects the all slope systematically In this study. According to the slope unit approach, since the landslide-related processes take place on the slope, wide valley bases were excluded from the models. This approach affected the results positively.

Although the basic conditions such as slope and lithology affecting the landslide are common in most studies, TWI, SPI.. etc. conditions specific to some fields also affect them. Of course, it can also change according to the working scale. As the scale of the study area gets smaller, the area expands, and therefore the types of factors affecting landslides increase.

This study suggests that the conditions affecting the landslide should be obtained by research and analysis specific to the study area rather than random selection. In addition, we think that it would be more appropriate to focus on a single landslide type and choose a parameter specific to it. Because conditions and results may change according to the type of landslide.

In this direction, the correct selection of the parameters affecting the landslide was ensured by geomorphological analysis of the study area with this study. Models were created using the basic parameters determined for the slip-type landslide. Precipitation data, which is the triggering factor in the models, is considered equal in the whole area since there is only one meteorological data station for the study area. The aim here is to predict in which areas a landslide may occur when the precipitation exceeds the threshold value for the study area.

In the results in the raster-based model, the susceptibility results of the slope unit were determined according to the majority value covered by the cells in each slope unit. The M-AHP vector-based model was run as a slope unit. The results of the CBS Matrix model, which is another vector-based model, were determined according to the majority value in each slope unit, just like the raster-based model.

The results of these different types of models, ranging from raster-vector-based and qualitativequantitative methods, were clearly revealed some results for the studied region. 
The highest value of the receiver operating characteristic (ROC) curve obtained according to the model results was found in the CBS Matrix model (0.92). In terms of value, the models from high to low are AHP (0.87), frequency ratio (0.86), Weighted overlay (0.86), M-AHP (0.79), respectively (Fig. 9).

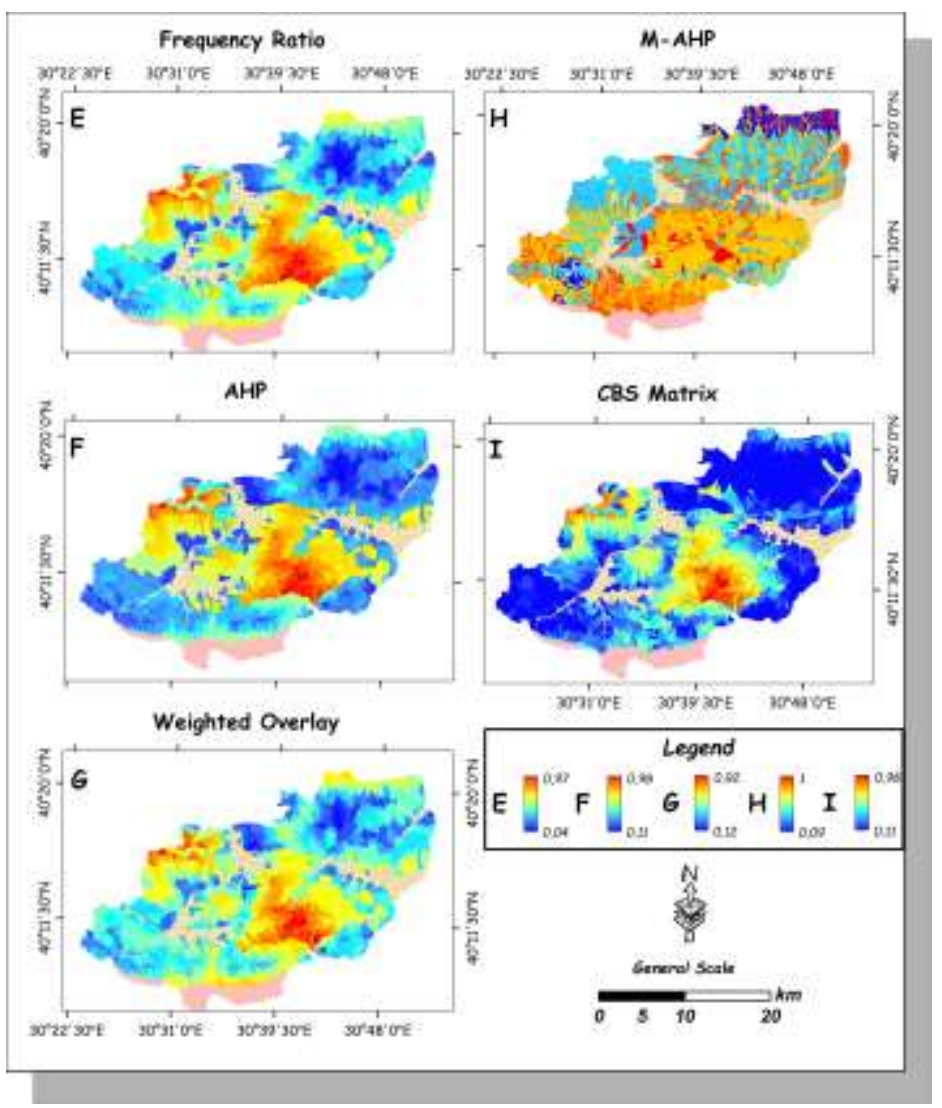

Fig. 8: Vector and raster-based model outputs

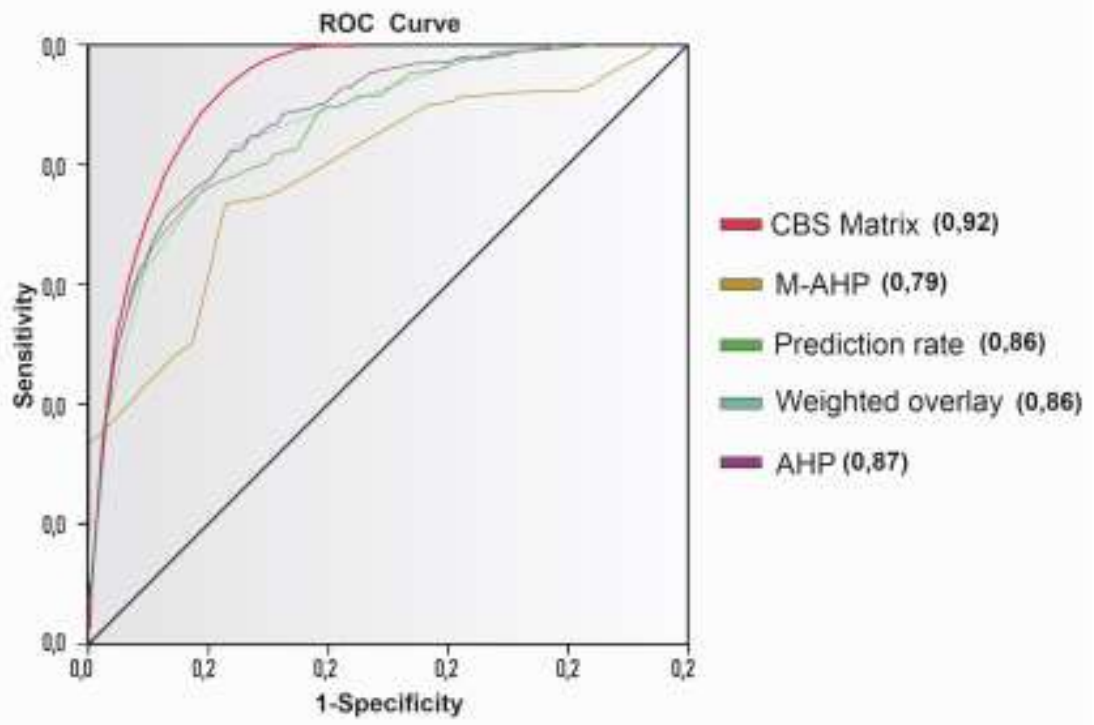


Fig. 9: Illustration of receiver operating characteristic (ROC) curve for different models.

The highest and lowest susceptibility areas in both raster and vector outputs correspond to close and common areas in all models (Fig. 8). Especially the West and Northwest regions of the study area correspond to low landslide susceptibility areas. It is thought that this is due to the correct parameter selection. The transition values between the lowest and highest values differ according to the models. The model with the largest difference is the M-AHP output (Fig. $8 \mathrm{H}$ ). The main reason for this is that the model gives results according to 3 sharp decision points (low, medium, and high) rather than a smooth transition in this model.

A hybrid model that can decide for the highest areas in terms of landslide susceptibility was revealed by combining all models where the common areas are close to each other (Fig. 10). In this way, the spatial susceptibility in the study area was determined by a joint decision of the different models rather than a single model. This model was made to provide practicality and reliability in terms of use.

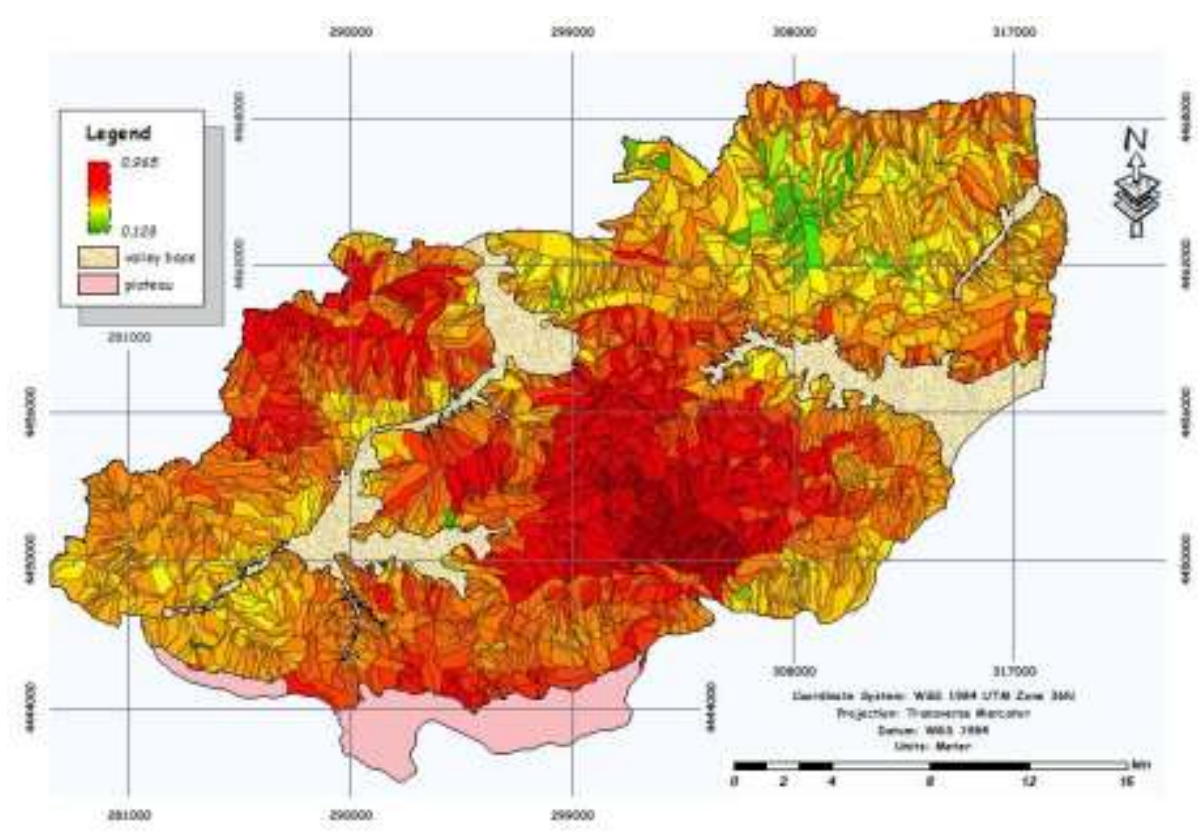

Fig. 10: A hybrid model derived from a combination of vector and raster-based models.

1)This study with the high success achieved above a positive effect on the results when the parameters to be used in a landslide susceptibility study is chosen specifically for the study area rather than random selection. 2) The study unites models with different bases such as raster or vector, and models with different approaches such as qualitative or quantitative on a common denominator in terms of susceptibility. 3) In general, the commonness of minimum and maximum landslide susceptibility areas in all models clearly reveals the safe and unsafe space. 4) Since the minimum and maximum landslide susceptibility areas are common in all models, the combined model clearly reveals the safe and unsafe areas. 5) As a hybrid model, the model provides more reliable decisions with the success of all models. 


\section{Acknowledgments}

The author would like to thank Hakan Ahmet Nefeslioglu for their teachings and Muhterem Kucukonder for help. 


\section{References}

Atkinson PM, Massari R (1998) Generalised linear modelling of susceptibility to landsliding in the central Apennines, Italy. Computers \& Geosciences 24:373-385. doi:https://doi.org/10.1016/S0098-3004(97)00117-9

Ayenew T, Barbieri G (2005) Inventory of landslides and susceptibility mapping in the Dessie area, northern Ethiopia. Engineering Geology 77:1-15. doi:https://doi.org/10.1016/j.enggeo.2004.07.002

Basharat M, Shah HR, Hameed N (2016) Landslide susceptibility mapping using GIS and weighted overlay method: a case study from NW Himalayas, Pakistan. Arabian Journal of Geosciences 9:1-19.

Brabb EE, Pampeyan EH (1972) Preliminary map of landslide deposits in San Mateo County, California.

Carrara A (1977) Computer-based data bank and statistical analysis of slope instability phenomena.

Carrara A, Cardinali M, Detti R, Guzzetti F, Pasqui V, Reichenbach P (1991) GIS techniques and statistical models in evaluating landslide hazard. Earth surface processes and landforms $16: 427-445$.

Casagli N, Catani F, Puglisi C, Delmonaco G, Ermini L, Margottini C (2004) An inventorybased approach to landslide susceptibility assessment and its application to the Virginio River Basin, Italy. Environmental and Engineering Geoscience 10:203-216. doi:https://doi.org/10.2113/10.3.203

Chau K, Sze Y, Fung M, Wong W, Fong E, Chan L (2004) Landslide hazard analysis for Hong Kong using landslide inventory and GIS. Computers \& Geosciences 30:429-443. doi:https://doi.org/10.1016/j.cageo.2003.08.013

Chen W, Shirzadi A, Shahabi H, Ahmad BB, Zhang S, Hong H, Zhang N (2017) A novel hybrid artificial intelligence approach based on the rotation forest ensemble and naïve Bayes tree classifiers for a landslide susceptibility assessment in Langao County, China. Geomatics, Natural Hazards and Risk 8:1955-1977. doi:https://doi.org/10.1080/19475705.2017.1401560

Cihangir ME (2018) Kelkit Çayı Vadisinde (Umurca-Koyulhisar Arası) Heyelan Riskinin Belirlenmesi Unpublished $\mathrm{PhD}$ thesis, Istanbul University

Cihangir ME, Gorum T (2016) Kelkit Vadisinin Aşağı Çığrında Gelişmiş Heyelanların Dağılım Deseni ve Oluşumlarını Kontrol Eden Faktörler. Türk Cografya Dergisi 0. doi:10.17211/tcd.84731

Cihangir ME, Görüm T, Nefeslioğlu HA (2018) Heyelan tetikleyici faktörlerine bağlı mekânsal hassasiyet değerlendirmesi. Türk Coğrafya Dergisi:133-142. doi:https://doi.org/10.17211/tcd.410998 
Clerici A, Perego S, Tellini C, Vescovi P (2006) A GIS-based automated procedure for landslide susceptibility mapping by the conditional analysis method: the Baganza valley case study (Italian Northern Apennines). Environmental Geology 50:941-961. doi:DOI 10.1007/s00254-006-0264-7

Costanzo D, Rotigliano E, Irigaray C, Jiménez-Perálvarez JD, Chacón J (2012) Factors selection in landslide susceptibility modelling on large scale following the gis matrix method: application to the river Beiro basin (Spain). Natural Hazards and Earth System Sciences 12:327340. doi:https://doi.org/10.5194/nhess-12-327-2012

Cotecchia F, Lollino P, Santaloia F, Vitone C, Mitaritonna G (2009) A research project for deterministic landslide risk assessment in Southern Italy: methodological approach and preliminary results. Geotechnical risk and safety Taylor \& Francis Group, London:363-370.

Cruden DM (1993) Cruden, DM, Varnes, DJ, 1996, Landslide Types and Processes, Transportation Research Board, US National Academy of Sciences, Special Report, 247: 3675.

Dai F, Lee C (2002) Landslide characteristics and slope instability modeling using GIS, Lantau Island, Hong Kong. Geomorphology 42:213-228. doi:https://doi.org/10.1016/S0169$555 \mathrm{X}(01) 00087-3$

DeGraff JV, Romesburg HC (2020) Regional landslide — susceptibility assessment for wildland management: a matrix approach. Routledge

Du J, Glade T, Woldai T, Chai B, Zeng B (2020) Landslide susceptibility assessment based on an incomplete landslide inventory in the Jilong Valley, Tibet, Chinese Himalayas. Engineering Geology 270:105572. doi:https://doi.org/10.1016/j.enggeo.2020.105572

Eeckhaut M, Reichenbach P, Guzzetti F, Rossi M, Poesen J (2009) Combined landslide inventory and susceptibility assessment based on different mapping units: an example from the Flemish Ardennes, Belgium. Natural Hazards and Earth System Sciences 9:507-521. doi:https://doi.org/10.5194/nhess-9-507-2009

Ercanoglu M, Gokceoglu C (2002) Assessment of landslide susceptibility for a landslide-prone area (north of Yenice, NW Turkey) by fuzzy approach. Environmental geology 41. doi:DOI $10.1007 / \mathrm{s} 00254-001-0454-2$

Erener A, Düzgün HSB (2010) Improvement of statistical landslide susceptibility mapping by using spatial and global regression methods in the case of More and Romsdal (Norway). Landslides 7:55-68. doi:DOI 10.1007/s10346-009-0188-x

Fernández CI, Del Castillo TF, Hamdouni RE, Montero JC (1999) Verification of landslide susceptibility mapping: a case study. Earth Surface Processes and Landforms: The Journal of the British Geomorphological Research Group 24:537-544. doi:https://doi.org/10.1002/(SICI)1096-9837(199906)24:6<537::AID-ESP965>3.0.CO;2-6

Gorum T, Gonencgil B, Gokceoglu C, Nefeslioglu H (2008) Implementation of reconstructed geomorphologic units in landslide susceptibility mapping: the Melen Gorge (NW Turkey). Natural Hazards 46:323-351. doi:DOI 10.1007/s11069-007-9190-6 
Gökceoglu C, Aksoy H (1996) Landslide susceptibility mapping of the slopes in the residual soils of the Mengen region (Turkey) by deterministic stability analyses and image processing techniques. Engineering Geology 44:147-161. doi:https://doi.org/10.1016/S00137952(97)81260-4

Guzzetti F, Carrara A, Cardinali M, Reichenbach P (1999) Landslide hazard evaluation: a review of current techniques and their application in a multi-scale study, Central Italy. Geomorphology 31:181-216. doi:https://doi.org/10.1016/S0169-555X(99)00078-1

Guzzetti F, Reichenbach P, Cardinali M, Galli M, Ardizzone F (2005) Probabilistic landslide hazard assessment at the basin scale. Geomorphology 72:272-299. doi:https://doi.org/10.1016/j.geomorph.2005.06.002

Irigaray C, Fernández T, El Hamdouni R, Chacón J (2007) Evaluation and validation of landslide-susceptibility maps obtained by a GIS matrix method: examples from the Betic Cordillera (southern Spain). Natural hazards 41:61-79.

Juang C, Lee D, Sheu C (1992) Mapping slope failure potential using fuzzy sets. Journal of geotechnical engineering 118:475-494.

Kanungo D, Arora M, Sarkar S, Gupta R (2006) A comparative study of conventional, ANN black box, fuzzy and combined neural and fuzzy weighting procedures for landslide susceptibility zonation in Darjeeling Himalayas. Engineering Geology 85:347-366. doi:https://doi.org/10.1016/j.enggeo.2006.03.004

Kavzoglu T, Sahin EK, Colkesen I (2015) Selecting optimal conditioning factors in shallow translational landslide susceptibility mapping using genetic algorithm. Engineering Geology 192:101-112. doi:https://doi.org/10.1016/j.enggeo.2015.04.004

Lee S, Choi J, Min K (2004) Probabilistic landslide hazard mapping using GIS and remote sensing data at Boun, Korea. International Journal of Remote Sensing 25:2037-2052.

Lee S, Min K (2001) Statistical analysis of landslide susceptibility at Yongin, Korea. Environmental geology 40:1095-1113. doi:DOI 10.1007/s10346-006-0047-y

Lee S, Pradhan B (2007) Landslide hazard mapping at Selangor, Malaysia using frequency ratio and logistic regression models. Landslides 4:33-41.

Lee S, Talib JA (2005) Probabilistic landslide susceptibility and factor effect analysis. Environmental Geology 47:982-990. doi:DOI 10.1007/s00254-005-1228-z

Malamud BD, Turcotte DL, Guzzetti F, Reichenbach P (2004) Landslide inventories and their statistical properties. Earth Surface Processes and Landforms 29:687-711. doi:https://doi.org/10.1002/esp.1064

MTA (2002) 1:100 000 geology maps (Adapazari H24-H25). General Directorate of Mineral Research and Exploration, Ankara 
Nandi A, Shakoor A (2010) A GIS-based landslide susceptibility evaluation using bivariate and multivariate statistical analyses. Engineering Geology 110:11-20. doi:https://doi.org/10.1016/j.enggeo.2009.10.001

Nefeslioglu HA, Gokceoglu C, Sonmez H (2008) An assessment on the use of logistic regression and artificial neural networks with different sampling strategies for the preparation of landslide susceptibility maps. Engineering Geology 97:171-191. doi:https://doi.org/10.1016/j.enggeo.2008.01.004

Nefeslioglu HA, Sezer EA, Gokceoglu C, Ayas Z (2013) A modified analytical hierarchy process (M-AHP) approach for decision support systems in natural hazard assessments. Computers \& Geosciences 59:1-8. doi:https://doi.org/10.1016/j.cageo.2013.05.010

Okay Aİ (2011) Tavşanlı Zonu: Anatolid-Torid Bloku'nun Dalma-Batmaya Uğramış Kuzey Ucu. Maden Tetkik ve Arama Dergisi:195-226.

Pachauri A, Gupta P, Chander R (1998) Landslide zoning in a part of the Garhwal Himalayas. Environmental Geology 36:325-334.

Pachauri A, Pant M (1992) Landslide hazard mapping based on geological attributes. Engineering geology 32:81-100. doi:https://doi.org/10.1016/0013-7952(92)90020-Y

Pérez-Peña JV, Al-Awabdeh M, Azañón JM, Galve JP, Booth-Rea G, Notti D (2017) SwathProfiler and NProfiler: Two new ArcGIS Add-ins for the automatic extraction of swath and normalized river profiles. Computers \& Geosciences 104:135-150.

Phong TV, Phan TT, Prakash I, Singh SK, Shirzadi A, Chapi K, Ly H-B, Ho LS, Quoc NK, Pham BT (2019) Landslide susceptibility modeling using different artificial intelligence methods: A case study at Muong Lay district, Vietnam. Geocarto International:1-24. doi:https://doi.org/10.1080/10106049.2019.1665715

Roslee R, Mickey AC, Simon N, Norhisham MN (2017) Landslide susceptibility analysis (LSA) using weighted overlay method (WOM) along the Genting Sempah to Bentong Highway, Pahang. Malaysian Journal of Geosciences (MJG) 1:13-19. doi:https://doi.org/10.26480/mjg.02.2017.13.19

Ruff M, Czurda K (2008) Landslide susceptibility analysis with a heuristic approach in the Eastern Alps (Vorarlberg, Austria). Geomorphology 94:314-324. doi:https://doi.org/10.1016/j.geomorph.2006.10.032

Saaty T (1980) Analytical Hierarchy Process McGraw Hill Company. New York.

Santacana N, Baeza B, Corominas J, De Paz A, Marturiá J (2003) A GIS-based multivariate statistical analysis for shallow landslide susceptibility mapping in La Pobla de Lillet area (Eastern Pyrenees, Spain). Natural hazards 30:281-295.

Shit PK, Bhunia GS, Maiti R (2016) Potential landslide susceptibility mapping using weighted overlay model (WOM). Modeling Earth Systems and Environment 2:21. 
Tribe A (1991) Automated recognition of valley heads from digital elevation models. Earth surface processes and landforms 16:33-49. doi:https://doi.org/10.1002/esp.3290160105

Wachal DJ, Hudak PF (2000) Mapping landslide susceptibility in Travis County, Texas, USA. GeoJournal 51:245-253.

Westen Cv, Terlien M (1996) An approach towards deterministic landslide hazard analysis in GIS. A case study from Manizales (Colombia). Earth surface processes and landforms 21:853868 .

Yaralıŏlu K (2004) Decision Support Techniques in Application. Ilkem Ofset, İzmir.

Yesilnacar E, Topal T (2005) Landslide susceptibility mapping: A comparison of logistic regression and neural networks methods in a medium scale study, Hendek region (Turkey). Engineering Geology 79:251-266. doi:10.1016/j.enggeo.2005.02.002

Yilmaz H, Oezel S (2008) Crustal structure of the eastern part of Central Anatolia (Turkey). Turkish Journal of Earth Sciences 17:169-185.

Yilmaz I (2010) The effect of the sampling strategies on the landslide susceptibility mapping by conditional probability and artificial neural networks. Environmental Earth Sciences 60:505519. 